\title{
PENGARUH LEVERAGE, PROFITABILITAS, LIKUIDITAS, PERTUMBUHAN PERUSAHAAN, RISIKO BISNIS DAN PELUANG PERTUMBUHAN TERHADAP KEBIJAKAN DIVIDEN
}

\section{THE INFLUENCE OF LEVERAGE, PROFITABILITY, LIQUIDITY, COMPANY GROWTH, BUSINESS RISK, AND GROWTH OPPORTUNITIES ON DIVIDEND POLICY}

\author{
Roshidayah ${ }^{1}$ \\ 1 Universitas Islam Batik Surakarta - Surakarta \\ Email : Roshidayah713@gmail.com
}

\begin{abstract}
ABSTRAK
Penelitian ini bertujuan untuk menguji dan menganalisis Pengaruh Leverage, Profitabilitas, Likuiditas, Pertumbuhan Perusahaan, Risiko Bisnis dan Peluang Pertumbuhan terhadap Kebijakan Dividen. Populasi pada penelitian adalah perusahaan property dan real estate pada Bursa Efek Indonesia (BEI) pada 2016-2018. Sampel dipilih dari metode purposive sampling dan mendapatkan sample 36 perusahaan dari beberapa kriteria. Sumber data adalah data sekunder dari website (www.idx.co.id). Riset ini menggunakan analisis regresi linier berganda dengan bantuan program SPSS versi 20. Hasil dari riset ini menunjukkan bahwa Leverage, Profitabilitas, Likuiditas, Pertumbuhan Perusahaan, Risiko Bisnis dan Peluang Pertumbuhan tidak memiliki pengaruh terhadap Kebijakan Dividen.
\end{abstract}

Kata Kunci: Leverage, profitabilitas, likuiditas, pertumbuhan perusahaan, kebijakan dividen

\section{ABSTRACT}

This study aims to examine and analyze the Effects of Leverage, Profitability, Liquidity, Company Growth, Business Risk and Growht Opportunities on Dividend Policy. The population in this study are property and real estate companies on the Indonesia Stock Exchange (IDX) in 2016-2018.

The sample was selected from the purposive sampling is 36 companies from several criteria. The data source is secondary data from the website (www.idx.co.id). This research uses multiple linier regression analysis with the help of SPSS version 20. The results of this research show that Leverage, Profitability, Liquidity, Company Growth, Business Risk dan Growth Opportunities have on influence on Dividend Policy.

Keywords: Leverage, profitability, liquidity, company growth, dividend policy 


\section{PENDAHULUAN}

Kalangan analisis memproyeksikan pembagian dividen pada tahun ini masih sama dengan tahun sebelumnya. Kepala riset MNC Edwin Sebayang memproyeksikan, pembagian dividen dari laba 2018 berpotensi tidak jauh berbeda dari tahun sebelumnya. Sebab, kondisi ekonomi pada tahun 2018 masih mirip dengan 2017, bahkan ada beberapa sektor yang kurang baik. "sektor yang kurang baik pada 2018 yakni property, perkebunan (CPO), telekomunikasi, transportasi, baja dan semen," katanya saat dihubungi bisnis. Dalam kesempatan terpisah, analisis Bahana Sekuritas Muhammad Wafi menilai, raihan laba emiten pada 2018 masih sesuai dengan ekspektasi pasar. Menurutnya, kondisi tersebut juga akan berdampak baik pada rencana pembagian dividen pada tahun ini. Bila ditelisik dari pembagian dividen, katanya hal itu sangat bergantung dengan capaian laba 2018. Sebab, bila perusahaan sedang tidak membutuhkan banyak belanja modal, maka laba keseluruhan akan dibagikan kepada pemegang saham. (https://market.bisnis.com)

Dalam hal ini dividen merupakan keuntungan bagi perusahaan yang mana perusahaan tersebut memutuskan untuk membagikan kepada pemilik saham. Pemilik dividen yang diberikan kepada pemilik saham menerima dalam keadaan utuh tidak terpotong oleh pajak. Tetapi apabila perusahaan mengalami kerugian maka perusahaan tersebut tidak akan membayar dividen pada pemilik saham. Salah satu indikator penting dalam penelitian ini yaitu leverage, profitabilitas, likuiditas, pertumbuhan perusahaan, risiko bisnis dan peluang pertumbuhan yang berhubungan dengan dividend policy.

Leverage menunjukkan proporsi bagi penggunaan utangnya untuk membiayai investasi perusahaan. Marlina dan Clara (2009) berpendapat bahwa peningkatan hutang perusahaan akan memengaruhi besar kecilnya laba yang tersedia bagi para pemegang saham. termasuk juga dividen yang diterima karena kewajiban untuk membayar hutang lebih utama daripada membagi dividen.

Profitabilitas merupakan factor yang penting dalam kebijakan dividen. Karena laba merupakan indikator yang utama dalam menunjukkan kapasitas pembayaran dividen (Anil Kapoor 2008 dalam Marpung dan Hadianto 2009). Likuiditas yaitu kemampuan perusahaan dalam memenuhi kewajiban jangka panjang dan pendek melalui jumlah kasnya. Seperti giro atau simpanan lainnya milik perusahaan yang ada dibank yang bias ditarik sewaktu-waktu. Apabila likuiditas tinggi menunjukkan kemampuan kas perusahaan mampu memenuhi kewajiban pendeknya. Sehingga dapat mengambil likuiditas perusahaan berpengaruh terhadap dividend policy.

Apabila semakin cepat pertumbuhan suatu perusahaan maka semakin besar dan yang diperlukan dalam membiayai perusahaan. Jika semakin besar kebutuhan dana untuk waktu yang akan datang maka perusahaan tersebut lebih senang menanam labanya daripada membayar dividen kepada para pemegang sahamnya. Haryetti dan Ririn Araji (2012) berpendapat bahwa pertumbuhan perusahaan tidak berpengaruh terhadap dividend policy. Sedangkan menurut Riyanti Elysa (2010) menyatakan bahwa pertumbuhan perusahaan berpengaruh terhadap dividend policy. Risiko bisnis yang dihadapi suatu perusahaan akan meningkat dengan seiring meningkatnya penggunaan hutang. Hasil penelitian De Angelo (1990) bahwa perusahaan mengurangi dividen yang yang dibayarkan ketika sedang mengalami kesulitan keuangan.

Penelitian ini bermaksud merumuskan tentang apakah kebijakan deviden ( $Y$ ) berpengaruh dengan leverage $(X 1)$, profitabilitas $(X 2)$, likuiditas $(X 3)$, pertumbuhan perusahaan (X4), risiko bisnis (X5), peluang pertumbuhan (X6). Penelitian ini megambil data dari BEI laporan keuangan perusahaan property dan real estate tahun 2016-2018. Berdasarkan latar belakang penelitian bertujuan untuk meneliti mengenai pengaruh dari leverage, profitabilitas, likuiditas, 
pertumbuhan perusahaan, risiko bisnis dan peluang pertumbuhan. Manfaat dari penelitian ini adalah untuk menambah wawasan dan referansi tentang kebijakan deviden.

\section{LANDASAN TEORI}

\section{Teori Keagenan (Agency Teory)}

Pradana dan Sanjaya (2014) menyatakan bahwa munculnya biaya keagenan dapat diperkecil dengan cara melakukan pembagian dividen kepada pemegang sahamnya, sehingga perusahaan tidak memiliki dana terlalu berlebih yang menimbulkan peluang untuk disalah gunakan oleh berbagai pihak yang tidak bertanggung jawab. Sebagai sarana perusahaan agar investor yakin berinvestasi kembali pada perusahaannya, pembayaran dividen bisa digunakan sebagai alat pengawasan pemegang saham pada pihak manajemen perusahaan.

\section{Kebijakan Deviden}

Riyanto (1995) deviden merupakan aliran kas yang dibayarkan kepada pemegang saham. Dividend payout ratio digunakan untuk mengetahui persentase dari pendapatan yang akan dibayarkan kepada pemegang saham cash dividend.

\section{Leverage}

Dalam penelitian ini leverage dihitung dengan menggunakan Debt to Equity Ratio (DER). DER yaitu ratio yang digunakan untuk menunjukkan kemampuan dalam memenuhi seluruh kewajiban yang ditunjukkan oleh beberapa modal sendiri yang digunakan untuk membayar hutang (jalung, 2017). DER yaitu membandingkan antara total kewajiban dengan total modal sendiri. Rasio menunjukkan bahwa sejauh mana total sendiri menjamin semua utang. Apabila DER tinggi berarti perusahaan sudah melaksanakan pembiayaan yang agresif sehingga perusahaan tersebut tumbuh bersamaan dengan utangnya. Semakin besar DER berarti semakin besar pula ketergantungan perusahaan terhadap pihak eksternal (kreditur) maka semakin besar pula perusahaan harus membayar beban biaya hutangnya. Peningkatan hutang ini akan mempengaruhi besar kecilnya laba bersih bagi pemegang saham termasuk dividen yang akan diterima.

\section{Likuiditas}

Likuiditas perusahaan menunjukkan bahwa kemampuan perusahaan mendanai operasional perusahaannya dan melunasi kewajiban jangka pendeknya. Likuiditas suatu perusahaan merupakan faktor penting yang harus dipertimbangkan dalam mengambil keputusan untuk menetapkan seberapa besarnya dividen yang akan dibayar kepada para pemegang saham. Maka semakin kuatnya posisi likuiditas perusahaan maka semakin besar kemampuan untuk membayar dividen. Hal ini menunjukkan bahwa semakin kuat posisi likuiditas perusahaan pada prospek kebutuhan dana, maka akan semakin tinggi rasio pembayaran dividen.

\section{Profitabilitas}

Profitabilitas merupakan kemampuan perusahaan dalam menghasilkan laba, dan laba inilah yang akan menjadi dasar pembagian dividen perusahaan (Sari,2008). Apabila tingkat profitabilitas perusahaannya tinggi, maka semakin besar laba yang dihasilkan perusahaan dalam bentuk dividen kepada pemegang saham. Profitabilitas yaitu kemampuan perusahaan dalam memperoleh laba bersih dari kegiatan operasionalnya. ROA dapat menunjukkan kemampuan perusahaan dengan memperoleh keuntungan dari asset atau aktiva yang digunakan. Dividen yaitu laba bersih yang diperoleh perusahaan, karena itu dividen akan dibagikan jika perusahaan memperoleh keuntungan. 


\section{Pertumbuhan Perusahaan}

Semakin tinggi tingkat perusahaan, maka semakin besar tingkat kebutuhan dananya. Jika semakin besar kebutuhan dana dimasa yang akan datang, maka semakin memungkinkan bahwa perusahaan tidak membayarkan sebagai dividen dan menahan keuntungannya. Oleh sebab itu, pertumbuhan perusahaan menjadi factor yang penting untuk menentukan kebijakan dividen. Sebagai pedoman yang digunakan dalam tingkat pertumbuhan yang diatur setiap tahun dalam total asset (Chang dan Rhee, 1990).

\section{Risiko Bisnis}

Jika perusahaan memiliki risiko bisnis yang tinggi, maka perusahaan cenderung kurang dapat menggunakan hutang yang besar. Tinggi rendahnya risiko bisnis bisa dilihat dari stabilitas harganya.

\section{Peluang Pertumbuhan}

Kartini dan arianto (2008) mendefinisikan bahwa peluang pertumbuhan adalah perubahan pada total aktiva yang memiliki oleh perusahaan. Besaran ini mengukur sejauh mana laba perlembar saham pada suatu perusahaan dapat meningkatkan leveragenya. Perusahaan-perusahaan yang memiliki pertumbuhan cepat maka harus seringkali meningkatkan aktiva tetapnya.

\section{Pengembangan Hipotesis}

\section{Leverage terhadap kebijakan deviden}

Leverage menunjukkan kemampuan perusahaan dalam menghasilkan laba atas aktiva yang dipergunakan (Jalung, 2017). Rasio ini mengukur seberapa banyak laba bersih yang bisa diperoleh dari seluruh asset yang dimiliki dan ditanamkan kedalam sebuah perusahaan. Semakin tinggi tingkat pengembalian investasi, menunjukkan kinerja perusahaan semakin baik. Sebaliknya, apabila leverage (retrun on asset negative) menunjukkan bahwa total aktiva yang dipergunakan perusahaan mengalami kerugian dan berpengaruh dengan besar kecilnya deviden yang akan dibagikan. Rehman \& Takumi (2012) menyatakan bahwa DER memiliki hubungan positif denga kebijakan deviden.

$\mathrm{H}_{1}$ : Leverage berpengaruh terhadap kebijakan deviden

\section{Likuiditas terhadap kebijakan deviden}

(Riyanto, 1995) likuiditas merupakan perusahaan yang mendanai operasi perusahaannya dan memenuhi kewajiban jangka pendeknya. Likuiditas diartikan sebagai prbandingan antara jumlah uang tai dan aktiva lain yang dapat disamakan dengan uang tunai disatu pihak dengan jumlah utang lancer dipihak lain, juga dengan pengeluaran-pengeluaran untuk menyelenggarakan perusahaan dipihak lain. Semakin tinggi likuiditas perusahaan berarti semakin besar pula kemungkinan perusahaan membayar deviden. Dalam penelitian Sari (2015) menunjukkan bahwa Current Ratio berpengaruh positif dan signifikan terhadap kebijakan deviden.

$\mathrm{H}_{2}$ : Likuiditas berpengaruh terhadap kebijakan deviden

\section{Profitabilitas (ROA) terhadap kebijakan deviden}

Alzomaia \& Al-Khadhiri (2013), profitabilitas perusahaan saat ini dan tingkat deviden sebelumnya berpengaruh signifikan terhadap keputusan perusahaan untuk menaikkan atau menurunkan tingkat deviden dipasar saham Saudi. Hubungan positif ini menunjukkan bahwa perusahaan bersedian membayar deviden lebih banyak jika perusahaan mengalami peningkatan tingkat 
profitabilitas dengan pertimbangan tingkat deviden tahun lalu yang tinggi. Jadi tingkat profitabilitas bisa diukur dengan sejauh mana perusahaan mampu menghasilkan laba dari hasil operasinya. Peneliti Arihala (2009) hasil penelitian menunjukkan bahwa profitabilitas berpengaruh positif terhadap kebijakan deviden.

$\mathrm{H}_{3}$ : Profitabilitas (ROA) berpengaruh terhadap kebijakan deviden Pertumbuhan perusahan terhadap kebijakan deviden

Riyanto (1995) semakin cepat tingkat pertumbuhan perusahaa, maka semakin besar kebutuhan dana yang akan dibutuhkan perusahaan untuk mendanai pertumbuhannya. Semakin besar kebutuhan dana untuk membiayai pertumbuhannya, perusahaan akan lebih senang menahan labanya dibandingan dengan membayarkannya sebagai deviden. Dengan demikian pertumbuhan perusahaan akan berhubungan langsung dengan kebutuhan keuangan perusahaan, maka semakin besar dana untuk membiayai kebutuhan perusahaan maka kemungkinan besar perusahaan akan menahan laba dan tidak membayarkannya sebagai deviden. Lestari, dkk (2017) asset growth dinyatakan berpengaruh signifikan terhadap dividend payout ratio.

H4 : Pertumbuhan perusahaan berpengaruh terhadap kebijakan deviden

\section{Risiko bisnis terhadap kebijakan deviden}

Menurut Husnan (2006) setiap perusahaan akan mengalami risiko sebagai akibat karena melakukan operasi perusahaan. Apabila perusahaan yang risikonya tinggi pada umumnya akan membayar dividen lebih rendah karena dividen yang rendah dapat digunakan untuk menghindari pemotongan dividen dimasa yang akan datang. Penelitian ini menunjukkan risiko bisnis berpengaruh terhadap kebijakan dividen.

H5 : Risiko bisnis berpengaruh terhadap kebijakan deviden

\section{Peluang pertumbuhan terhadap kebijakan deviden}

Ahmed dan Javid (2009), Al-Kuwari (2010) dan Jensen (1986) berpendapat bahwa pertumbuhan perusahaan meningkat jika peluang ekonomi yang tersedia di pasar juga mengalami peningkatan. Oleh karena itu, mereka membayar dividen yang lebih rendah untuk pemegang saham. Penelitian ini mengidentifikasi bahwa peluang pertumbuhan berpengaruh terhadap kebijakan dividen.

H6 : Peluang pertumbuhan berpengaruh terhadap kebijakan deviden

\section{METODE PENELITIAN}

\section{Jenis dan Sumber Data Penelitian}

Jenis penelitian yang digunakan dalam penelitian ini yaitu kuantitatif, Sumber data dalam penelitian ini adalah data sekunder. Instrument penelitia ini merupakan dokumentasi yang berupa laporan keuangan perusahaan property dan real estate yang periode 2016-2018. Pengambilan sampel menggunakan purposive sampling. Jumlah populasi 135 perusahaan yang memenuhi kriteria sebanyak 42 perusahaan, maka data penelitian $14 \times 3$ tahun yaitu 42 data.Perusahaan yang menyampaikan datanya dengan lengkap sesuai dengan informasi yang diperlukan. Penggunaan teknis analisis regresi linier berganda dalam penelitian ini menggunakan program SPSS versi 21 untuk melakukan uji asumsi klasik serta melakukan uji hipotesis. Berikut persamaan regresi linier berganda pada penelitian ini :

Model regresi : $Y=a+\left(B_{1}\right.$ prof $)+\left(B_{2}\right.$ likuidasi $)+\left(B_{3}\right.$ leverage $)+\left(B_{4}\right.$ growth $)+e$ 
Dimana:

a

$B$

Kebijakan Deviden

Profitabilitas

Likuiditas

Leverage

Pertumbuhan Perusahaan
: Konstanta

: Koefisien Regresi

: Dividend Payout Ratio (DPR)

: Return on Asset (ROA)

: Current Ratio (CR)

: Debt to Equity Ratio (DER)

: Growth

\section{HASIL DAN PEMBAHASAN}

Penelitian ini menganalisis pengaruh rasio keuangan dan ukuran perusahaan terhadap kebijakan dividen pada perusahaan property dan real estate yang terdaftar di Bursa Efek Indonesia tahun 2016-2018. Sumber data yang digunakan dalam penelitian ini adalah data sekunder yang diperoleh dari www.idx.co.id. Dalam penelitian ini metode pemilihan sampel menggunakan teknik purposive sampling, yaitu pengambilan sampel berdasarkan kriteria tertentu. Berdasarkan hasil penelitian menggunakan metode purposive sampling, data perusahaan yang tidak terdaftar secara berturut-turut sebanyak 26 perusahaan selama periode 2016-2018. Perusahaan yang tidak menyajikan data secara lengkap sebanyak tidak ada. Sehingga diperoleh 40 perusahaan sebagai sampel penelitian. Penelitian yang dilakukan 3 periode, yaitu 2016-2018, maka sampel penelitian menjadi $3 \times 14=42$. Tidak terjadi outlier data dalam pengolahan data, sehingga sampel penelitian tetap 42 sampel perusahaan.

\section{Uji Deskriptif}

\section{Tabel 1. Hasil Uji Statistik Deskriptif}

Descriptive Statistics

\begin{tabular}{lrrrrr}
\hline & N & Minimum & Maximum & \multicolumn{1}{c}{ Mean } & \multicolumn{1}{c}{ Std. Deviation } \\
\hline DPR & 42 & 2016,0000000 & 2018,0000000 & 2017,000000000 &, 8263938705 \\
\hline DER & 42 &,- 0000025 & 124541563,299999 & 3332262,353354 & 19280268,94582 \\
& & & 9 & 470 & 51260 \\
\hline ROA & 42 &, 0006457 & 464127,9430000 & 11051,16854563 & 71616,41687196 \\
& & & & 8 & 25 \\
\hline CR & 42 &, 0000257 & 3646677,4720000 & 87913,98513227 & 562566,7054257 \\
& & & & 2 & 024 \\
\hline GROWTH & 42 &, 3401120 & 3068026,7170000 & 79254,05704892 & 474132,1569453 \\
& & & & 0 & 607 \\
\hline RISIKO_BISNI & 42 & 7403,0000000 & 41782800000000,0 & 3661192383785, & 8160577041796, \\
S & & & 000000 & 499500000 & 8680000000 \\
\hline PELUANG_P & 42 &, 0010035 & 1023,6044510 & 25,253427841 & 157,8064629809 \\
ERTUMBUHA & & & & & \\
N & & & & & \\
\hline Valid N & 42 & & & & \\
(listwise) & & & & & \\
\hline SumberData : BEl, Diolah dengan SPSS V 21, & & & \\
\hline
\end{tabular}

Sumber Data : BEl, Diolah dengan SPSS V.21, (2019) 
Berdasarkan tabel 2 uji statistik deskriptif variabel DPR, Leverage, Profitabilitas, Likuiditas, Pertumbuhan Perusahaan, Risiko Bisnis dan Peluang Pertumbuhan. Memiliki nilai rata-rata lebih besar dari nilai standar deviasi. Hal ini menunjukkan bahwa kualitas data dari variabel tersebut baik, karena nilai rata-rata lebih besar dari nilai standar deviasinya mengindentifikasikan bahwa standar error dari variabel tersebut kecil.

\section{Uji Asumsi Klasik}

Tabel 2. Hasil Uji Normalitas

\begin{tabular}{|c|c|c|c|}
\hline & $\begin{array}{c}\text { Kolmogorov- } \\
\text { Smirnov }\end{array}$ & $\begin{array}{l}\text { Asymp. Sig } \\
\text { (2-tailed }\end{array}$ & Unstandardized Residual \\
\hline $\begin{array}{l}\text { Unstandardized } \\
\text { Residual }\end{array}$ & 0,05 & 0,96 & Data Terdistribusi Normal \\
\hline
\end{tabular}

Tabel 6. Hasil Uji Regresi Linier Berganda

\begin{tabular}{|c|c|}
\hline \multirow{2}{*}{ Variabel } & Unstandardized Coefficients \\
\hline & $B$ \\
\hline (Constant) & 2016,989 \\
\hline DER & $-7,949 \mathrm{E}-009$ \\
\hline ROA & $2,145 \mathrm{E}-006$ \\
\hline CR & $3,073 \mathrm{E}-007$ \\
\hline GROWTH & $3,414 \mathrm{E}-009$ \\
\hline RISIKO_BISNIS & $-1,106 \mathrm{E}-013$ \\
\hline PELUAN̄E_PERTUMBUHAN & 0,001 \\
\hline
\end{tabular}

Sumber Data : BEl, Diolah dengan SPSS V.21, (2019)

Berdasarkan model diatas, dapat diketahui bahwa nilai konstanta sebesar 2016,989. Dengan nilai tersebut maka dapat diartikan bahwa Kebijakan Dividen akan bernilai 2016,989 apabila masing-masing variabel Debt to Equity Ratio (DER), Profitabilitas (ROA), Current Ratio (CR), Pertumbuhan perusahaan (Growht) dan Risiko Bisnis dan Peluang Pertumbuhan bernilai 0. DER mempunyai koefisiensi regresi sebesar -7,949E-009 mempunyai arti setiap kenaikan 1 satuan maka akan menaikkan nilai perusahaan 7,949E-009. ROA mempunyai koefisiensi regresi sebesar 2,145E-006 mempunyai arti setiap kenaikan 1 satuan ROA dengan asumsi variabel lain tetap maka akan menaikkan nilai perusahaan 2,145E-006. CR mempunyai koefisiensi regresi sebesar 3,073E-007 mempunyai arti setiap kenaikan 1 satuan CR dengan asumsi variabel lain tetap maka akan menaikkan nilai perusahaan 3,073E-007. Growht mempunyai koefisiensi regresi sebesar 3,414E-009 mempunyai arti setiap kenaikan 1 satuan Growht dengan asumsi variabel lain tetap maka akan menaikkan nilai perusahaan 3,414E-009. Risiko Bisnis mempunyai koefisiensi regresi sebesar -1,106E-013 mempunyai arti setiap kenaikan 1 satuan Risiko Bisnis dengan asumsi variabel lain tetap maka akan menaikkan nilai perusahaan $-1,106 \mathrm{E}-013$. Peluang Pertumbuhan mempunyai koefisiensi regresi sebesar 0,001 mempunyai arti setiap kenaikan 1 satuan Peluang Pertumbuhan dengan asumsi variabel lain tetap maka akan menaikkan nilai perusahaan 0,001 . 
Tabel 8. Hasil Uji T

\begin{tabular}{lccccc}
\multicolumn{1}{c}{ Hipotesis } & thitung & tabel & Sig & Standar & Ket. \\
\hline $\mathrm{H}_{1}$ (Leverage) & $-1,185$ & $>-2,018$ & 0,244 & $>0.05$ & Ditolak \\
\hline $\mathrm{H}_{2}$ (Profitabilitas) & 1,339 & $<2,018$ & 0,189 & $>0.05$ & Ditolak \\
\hline $\mathrm{H}_{3}$ (Likuiditas) & 1,193 & $<2,018$ & 0,241 & $>0.05$ & Ditolak \\
\hline $\mathrm{H}_{4}$ (Pertumbuhan Perusahaan) & 0,013 & $>2,018$ & 0,990 & $>0.05$ & Ditolak \\
\hline $\mathrm{H}_{5}$ (Risiko Bisnis) & 0,662 & $>2,018$ & 0,512 & $>0.05$ & Ditolak \\
\hline $\mathrm{H}_{6}$ (Peluang Pertumbuhan) & 1,207 & $<2,018$ & 0,236 & $>0.05$ & Ditolak \\
\hline
\end{tabular}

Sumber Data : BEI, Diolah dengan SPSS V.21, (2019)

Nilai - $t$ hitung $\leq \mathrm{t}$ tabel $\leq \mathrm{t}$ tabel $(-2,018 \leq-1,185 \leq 2,018)$ dan signifikasi $>0,05(0,244>0,05)$ maka $\mathrm{HO}$ diterima, jadi dapat disimpulkan bahwa leverage, likuiditas, profitabilitas, pertumbuhan perusahaan, risiko bisnis dan peluang pertumbuhan tidak berpengaruh terhadap kebijakan dividen.

Tabel 9. Hasil Uji Determinasi $\left(\mathbf{R}^{2}\right)$

\begin{tabular}{cccc}
\hline Model & Adjusted R Square & \multicolumn{2}{c}{ Keterangan } \\
\hline 1 & 0,157 & Variabel & leverage, \\
& likuiditas, profitabilitas, \\
& pertumbuhan perusahaan, \\
& risiko bisnis dan peluang \\
& pertumbuhan secara & simultan berpengaruh \\
& terhadap kebijakan dividen \\
& sebesar $15,7 \%$ \\
\hline
\end{tabular}

Sumber Data : BEI, Diolah dengan SPSS V.21, (2019)

Dari tabel 10 , nilai $R$ didapay 0,208 artinya terjadi hubungan yang erat karena nilainya melebihi 0,05 dan mendekati 1 . Nilai adjustes $R^{2}$ menunjukkan 0,157 artinya berpengaruh variabel independen terhadap variabel dependen sebesar $15,7 \%$.

\section{REKOMENDASI KEBIJAKAN}

\section{Rekomendasi}

1. Untuk peneliti selanjutnya diharapkan untuk memperluas sampel penelitian dan memperpanjang periode pengamatan.

2. Bagi peneliti selajutnya sebaiknya menambah variabel lain yang belum diteliti dalam penelitian ini.

\section{Kebijakan}

Penelitian ini dilakukan pada perusahaan property dan real estate yang terdaftar di BEl selama tiga tahun berturut-turut tahun 2016-2018 dan penelitian ini hanya menggunakan enam variabel yaitu Leverage, Profitabilitas, Likuiditas, Pertumbuhan Perusahaan, Risiko Bisnis dan Peluang Pertumbuhan. 


\section{DAFTAR PUSTAKA}

Jalung, K., mangantar, M., \& Mandagie, Y. (2017). analisis fator-fator yang mempengaruhi deviden payout ratio pada sub sektor bank yang terdaftar di BEI. jurnal emba.

Kusuma, o., \& samuel, h. (2019). The Effect of Company Performance on Dividend Policy in Manufacturing Companies. PETRA INTERNATIONAL JOURNAL OF BUSINESS STUDIES, VOL. 2, 87-95 .

Larasati, s., titisari, k. h., \& nurlaela, s. (2017). pengaruh good corporate governance dan corporate social responsibility terhadap kinerja keuangan perusahaan manufaktur yang terdaftar di BEl. seminar nasional IENAC, 579-586.

Munawir. (2007). Analisis Laporan Keuangan. Cetakan Keempat Belas. Yogyakarta: Liberty.

Mustofa, E. W., \& Singapurwoko. (2011). The Impact of Financial Leverage to Profitability Study if Non-Financial Companies Listed in Indonesia Stock Exchange. Euro Journals.

oktavia , I., \& basana , s. r. (2015). analisa faktor-faktor yang mempengaruhi kebijakan deviden . journal of reaserch in economics and management vol 13, 361-370.

Ratnasari , P. S., \& Purnawati , N. K. (2019). PENGARUH PROFITABILITAS, LIKUIDITAS, TINGKAT PERTUMBUHAN PERUSAHAAN DAN LEVERAGE TERHADAP KEBIJAKAN DIVIDEN . E-Jurnal Manajemen, Vol. 8, No. 10, 6179-6198.

Riyanto, B. $(2019$, 09). Browser. Diambil kembali dari konomi.blogspot.com: https://bahasekonomi.blogspot.com/2019/09/pengertian-dan-rumus-ukuranperusahaan.html?m=1

Rofique, m. (2012). faktor yang memengaruhi dividen payout bukti dari perusahaan non keuangan saham karachi bertukar. manajemen bisnis dynamics, 76-92.

Samuel, h., \& kusuma, o. (2019). The Effect of Company Performance on Dividend Policy in Manufacturing Companies. PETRA INTERNATIONAL JOURNAL OF BUSINESS STUDIES, VOL. 2, 87-95.

Sari, k. a., \& sudjarni, I. k. (2015). pengaruh likuiditas, leverage, pertumbuhan perusahaan, dan profitabilitas terhadap kebijakan dividen pada perusahaan manufaktur di BEI . e-journal manajemen unud vol 4, 3346-3374.

Sari, m. r., oemar, a., \& andini, r. (2016). pengaruh pertumbuhn perusahaan, ukuran perusahaan, earning per share, current ratio, retrun on equity dan debt to equity ratio terhadap kebijakan deviden pada perusahaan manufaktur di BEI tahun 2011-2014. journal of accounting.

Sartono, A. R. (2010). Manajemen keuangan Teori dan Aplikasi. Edisi Keempat. Yogyakarta: BPFE. 
Sawir, A. (2000). Analisis Kinerja Keuangan dan Perencanaan Keuangan Perusahaan. PT Gramedia Pustaka Utama.

Ullah , K., Bagh , T., \& Arif, D. (2019 ). Factors Affecting Dividend Policy: An Empirical Investigation of Food Sector of Pakistan, Vol.10, No.5 . Research Journal of Finance and Accounting .

Zais, G. (2017). Faktor-faktor yang mempengaruhi kebijakan deviden pada perusahaan industri barang konsumsi di Bursa Efek Indonesia . jurnal kompetitif vol 6, 10-28. 